\title{
Efficacy of Online Group Counseling with Mindfulness-Based Cognitive Approach to Enhance Students' Humility
}

\author{
Rohmatus Naini*, Mungin Eddy Wibowo, (D) Mulawarman Mulawarman \\ Universitas Negeri Semarang, Indonesia \\ هrohmatusnaini@students.unnes.ac.id*
}

\begin{abstract}
Character building is an important part of the counseling services in schools. Humility is a character strength as a basic development of others' virtue. This study aims to examine the effectiveness of online group counseling with a mindfulness-based cognitive approach to enhance students' humility. This study is a pretest-posttest control group design with 16 students divided into experimental and control groups. To measure the students' humility, the authors used 32 items of humility scale ( $\alpha=.901$ ). Furthermore, to measure mindfulness skills using children and adolescence mindfulness measurement $(\alpha=.790)$. Based on the results of the paired t-test data analysis, obtained the pretest-posttest $(t=18,391 ; p$ $=.56)$, posttest - follow up $(t=-5,769 ; p=.001)$, and pretest - follow up ( $t$ $=-30.549 ; p=.001)$. There was a significant change in the humility score which was marked by $(p<.05)$. Comparison analysis between the control group (MD $=12.62 ; \mathrm{SE}=.87 ; \mathrm{p}=.001$ ) was interpreted as a significant increase change in the students' humility. In addition, there is a significant interaction between students' humility in the group as evidenced by ( $F$ $\left.(2,4)=56,764, P=.001, \eta_{p} 2=.73\right)$. As the result, there is a significant change in mindfulness group counseling effect on increasing humility and has a large interaction effect.
\end{abstract}

Article Information:

Received December 31, 2020

Revised January 22, 2021

Accepted January 27, 2021

Keywords: humility; mindfulness-based cognitive; online group counseling

\section{INTRODUCTION}

Character education is part of the critical role of school counselors as a pioneer by providing services in the scope of personal social and mental health problems. This character is when viewed from Bronfenbrenner's (1992) theory of ecological systems, influences individual interactions in their life processes. Individuals who have good character tend to have self-confidence, and can work together, can socialize and communicate, concentrate, and feel empathy. Besides, adolescents with high character and emotional intelligence will avoid common problems such as delinquency, fights, drugs, alcohol, free sex behavior, and academic problems. Meanwhile, Kosim (2012) states that there are pillars of character that came from universal noble values, one of them is humility.

Humility or humility is one of the sub-factors of the HEXACO personality model, six factors that are also an integral part of the personality-building process (Sariçam et al., 2012). It is also a character strength depicted in the positive psychology movement (Snyder \& Lopez, 2009). Humility as a moral virtue is measured by assessing self-efficacy and the ability to admit mistakes, limitations, and imperfections (Tangney, 2000).

Davis et al. (2010) describe that humble individuals can let go of the ego, suppress the need to look right at every opportunity, and can take a longer view. Opinion according to

How to cite:

E-ISSN:

Published by:
Naini, R., Wibowo, M., \& Mulawarman, M. (2021). Efficacy of Online Group Counseling with MindfulnessBased Cognitive Approach to Enhance Students' Humility. Islamic Guidance and Counseling Journal, 4(1). https://doi.org/10.25217/igcj.v4i1.1280 2614-1566

Institut Agama Islam Ma'arif NU (IAIMNU) Metro Lampung 
(Niemiec et al., 2012) that individuals who have humility have modesty and tend to let one's achievements speak for themselves, meaning that humble individuals do not excel at their achievements.

Wright et al. (2017) explained a relationship between humility and several positive attributes and character strength. Humility is emphasized as a strong pro-social virtue with psychological, moral, and social benefits - true humility as a virtue basis to develop another good character. The measurement results of humility have a relationship with psychological well-being such as optimism, hope, achievement value, positive life rewards, positive growth, personal relationships, assertiveness, comfort with ambiguity, and openness to experience. Also, humility relates to intrinsic religiosity and faith maturity, and belief in freedom and dualism. Humility also has a positive relationship with various attributes related to morals or quality, for example being a responsible citizen, grateful (gratitude), humanist, empathy, moral identity, integrity, universal values, generosity, doing good, and also being used as a citizen. One's the moral foundation.

Humility has a negative relationship with sadistic behavior, feelings of insecure or anxious attachments, and economic or social greed. Individuals with low humility tend to have excessive self-confidence, are arrogant, and tend to commit contempt. The arrogance tends to lead to an assessment that he is superior to others, looks superior, and encourages him to be arrogant. This arrogance creates pride and looks down on others (Çardak, 2013; Rowatt et al., 2006). This will hinder individuals from social interaction, while humble people have their main abilities and strengths hidden from others, not being used to carry out negative behavior.

Rowatt et al. (2006) state that the antonym of humility is selfish, arrogant, and narrowminded. The selfish makes individuals often disliked. In an intellectual context, individuals who have low humility will appear arrogant and seem to know everything, even though they have a high intellect, it is not necessarily high humility. Sandage et al. (2017) explain a connection between humility and narcissism because it tends to display a pattern of grandeur, wanting to be admired, a lack of empathy, and arrogance which is masked by the character of humility. There is a positive relationship between humility and intellectual arrogance (Davis et al., 2010). This is reinforced by Rowatt et al. (2006) that implicitly, and explicitly humility has a relationship with arrogance. However, individuals who have humility will show emotional stability and positive feelings about themselves and the impact of low humility will be closely related to academic performance.

Several previous studies that have some interventions used to increase humility, namely Permatasari (2015), show that transactional analysis group counseling can foster student humility. This study recommends research to increase humility in a large sample, to can be generalized widely. There is also an intervention by Lavelock et al. (2014) using a workbook which results in effectiveness in increasing humility with a duration of $5-7.5$ hours by filling out activity reports. The limitation is that the workbook is not useful as the psychoeducation or psychotherapy group, because full participation does not become a guarantee as a research subject and recommends various backgrounds, types of population, and long-term impact of meaning. Van Tongeren et al. (2019) recommends that an intervention in the form of counseling is needed to increase humility by looking at the effectiveness of the effect of the intervention. Krumrei-Mancuso et al. (2020) recommend that an intervention for humility is needed in pro relational development with other characteristics such as gratitude, generosity, forgiveness. Although there have not been many studies that specifically improve humility, looking at these supporting characteristics, mindfulness interventions have been used in previous researchers, for example, Weber et al. (2013) explained that mindfulness is related to self-forgiveness, the forgiveness of others, and forgiveness of situations. Mindfulness has a potential impact on the forgiveness process (Orcutt, 2006). 
Mindfulness is described as not only a practice, but also as defined by conditions, properties, a process, and a result (Singh et al., 2008). So that it can be interpreted that mindfulness can be used by verbs, adjectives, and nouns. Mindfulness, according to Vernon \& Doyle (2017) is a form of awareness and full attention related to the present.

Van Doesum et al. (2020) explained that mindfulness was found to be related to personality traits that are associated with pro-social or antisocial behavior. The positive relationship between mindfulness and empathy, social value orientation, and negatively related to moral disengagement and narcissism. His research also found a powerful relationship between mindfulness and honesty-humility in the HEXACO construct.

According to Bishop et al. (2006) that there are two main components in mindfulness. The first is the self-regulation of attention, where the individual has an awareness of the experience, the feeling is fully present in the present moment. Besides, the focus is shifted from one object to another object flexibly. The attention raised will help optimize existing resources with existing information, generate perspectives on a broader experience, and metacognitive skills (self-regulation - monitoring self-awareness and control of cognitive processes). Second, experience orientation, meaning that individuals are in an active process to have a more open attitude and acceptance of new experiences and the thought process is also not self-centered.

Based on research conducted by Pang \& Ruch (2019) regarding the mindfulness model and character strength with an online system (pre-test and post-test as well as guidelines for implementing mindfulness at home available via email). However, this study has several limitations, namely online-based research so that there is a bias in the selection of participants who may have a previous understanding of positive psychology. Besides, the number of samples has little influence on the statistical analysis process. Another weakness is that the participants always complete the mindfulness measurement first then the character strength scale; this results in the effect of the subject's answer. There is no specification of the character studied strength so that no specific character is observed to see a change. Current research is based on the recommendation that character specifications are needed in research related to mindfulness interventions. Cybercounseling can improve wellbeing and academic performance (Hernawati et al., 2018).

Current research determines the humble character strengths by reviewing the effectiveness of mindfulness-based cognitive therapy and brief solution-focused counseling. Looking at some of the weaknesses of previous research, the setting that will be carried out in the current research is group counseling. One model of intervention with mindfulness is Mindfulness-based cognitive therapy. Mindfulness-based cognitive therapy or abbreviated as MBCT (Segal, Teasdale, \& Williams, 2013) praxis focuses on acceptance, letting go, patience, and openness which are also related to character strengths such as self-regulation and retrieval. Research related to MBCT tested with character strength variables has not been found. MBCT is often used as an intervention to engage in clinical research subjects. The MBCT concept is in line with the humility construct, including through mindfulness, individuals learn to regulate attention and elaborate on awareness of experiences and quality that is closely related to an experience with a curiosity orientation, openness to experience, and acceptance (Bishop et al., 2006), this is in line with several aspects of humility (Elliott, 2010) including openness; open to new ideas, accept abilities and accept suggestions from others. Also, this acceptance is associated with how individuals can accept themselves in line with aspects of accurate self-assessment, both understanding and accepting advantages and disadvantages. When individuals have humility, they try to let go and move on. So that they can become humble individuals, this concept is in harmony with humility in Elliott's (2010), theory including, openness, self-forgetfulness, accurate self-assessment, and focus on others. 
Mindfulness research in school settings is still limited, but several previous studies including (Nurhaeda et al., 2020) examined deep breathing techniques on mindfulness to increase the resilience of disabled students. Similar research was also conducted by Kurnaedi, Sugiharto, and Sunawan (2020) that mindfulness deep breathing can improve academic engagement in classroom learning settings. Both use practicing mindfulness only one technique instead of the whole. In contrast to the current research, the five sessions on mindfulness-based cognitive were given several techniques and worksheets for students.

Research on MBCT in school settings has been carried out by Susanti et al. (2020), but the limitation of this study is that it only uses one MBCT technique, namely meditation and it is only done once. The difference with the current research is using skills including meditation, eating, sitting meditation, 3-minutes breathing, self-compassion meditation, practicing gratitude, and developing an activity plan. Apart from being done together, the subjects were also given a home assignment by practicing independently at home for 5 five days recorded in a daily journal.

Problems are also found in educational settings; namely, students are less open in conveying the problems they face because they have a fear of teachers when doing face-toface counseling, the problems faced also tend to be privacy issues, so students need comfort in conveying. Furthermore, students also prefer and use the internet more often (Siradjuddin, 2017). The problem in face-to-face counseling is that clients often do not have time to come to the counselor, thus overriding the problems they have. Other obstacles are also experienced, namely lack of freedom, and feeling uncomfortable (Ussolikhah, 2017). From some of these obstacles, the researcher highlighted that to provide services that are not limited by space and time, online counseling services can be used. Based on the above review, the researcher wants to test the effectiveness of online group counseling with a mindfulness-based cognitive approach to increase students' humility.

\section{Rationale of the Current Study}

The current study is different from previous research because it specifically increases the strength of the humility character by reviewing the effectiveness of online group counseling with the Mindfulness-Based Cognitive approach. Looking at some of the weaknesses of previous research, the setting to be carried out in the current study is group counseling based. Besides, the mindfulness measurement itself will be carried out after the humility measurement.

Based on research conducted by Pang \& Ruch (2019) regarding mindfulness models and character strength with an online system (pre-test and post-test as well as guidelines for implementing mindfulness at home available via e-mail). However, this study has several limitations, namely online-based research so that there is a bias in the selection of participants who may have a previous understanding of positive psychology. Also, the number of samples has little influence on the statistical analysis process. Another weakness is that the participants always complete the mindfulness measurement first then the character strength scale, this results in the effect of the subject's answer. There is no specification of the strength of the character studied so that no specific character is observed to see a change. Current research is based on recommendations that character specifications are needed in research related to mindfulness interventions.

The implementation of counseling services using mindfulness practices can improve academic performance, coping skills, develop the quality of life and be able to have social skills (Tadlock-Marlo, 2011). Besides that, it can also increase student potential, students feel they have strength, can develop interpersonal relationships, and can have a more intense experience of achieving academic achievement in class, so that they are successful in academics and interpersonal. Brown \& Ryan (2003) explained that an example of the benefits 
of mindfulness practice is that it can have a positive relationship with pleasant effect, positive affect, increase self-confidence, feeling optimistic, overcoming neurotics, anxiety, and depression as well (Rodríguez-Ledo et al., 2018) with adolescent mindfulness practices had a better adjustment in school.

\section{Hypotheses}

1. Online group counseling with a mindfulness approach is effective in increasing students' humility

2. There is an interaction effect between the mindfulness and control groups when online group counseling is conducted with a mindfulness-based cognitive approach.

\section{METHODS}

\section{Research design}

This experimental research was a pretest-posttest control group design. There were two groups, namely the experimental group which was given mindfulness-based cognitive intervention, and the control group. Three stages in the data collection process including pretest, post-test, and follow-up. Counseling activities are conducted online. synchronous data collection for counseling and asynchronous for filling scales and worksheets.

\section{Participants}

There were 16 students (8 students in each group). The inclusion criteria of research subjects were students who had low humility based on humility scale measurements, had mindfulness skills as seen from Children and Adolescence Mindfulness Measurement (CAMM), had no experience of practicing mindfulness, and were willing to take online counseling.

\section{Instruments}

The instrument used is the Elliot humility scale which consists of 32 items adapted from Elliot (2010) theory covering four aspects including openness, self-forgetfulness, accurate self-assessment, and focused on others with a Likert scale type which has an answer range of 1-4 for favorable items, and 4-1 for unfavorable items. The reliability results of the humility scale were .901 while the CAMM consisted of 10 items, namely reliability $=.783$.

\section{Procedures}

The design of giving intervention for the experimental group consisted of 5 counseling sessions, each session following the counseling stages, namely the opening, transition, work, and closing stages. Activities carried out in the experimental group were session 1 (orientation, problem identification, and practicing short meditation and eating meditation), session 2 (understanding automatic pilots, practicing body scan \& sitting meditation), session 3 (practicing gratitude, forgiveness, and 3-minutes breathing), session 4 (understanding signs of stress and practicing self-compassion), and session 5 (preparing an activity plan). Meanwhile, the control group was given treatment as usual (TAU).

\section{Data Analysis}

Before the hypothesis testing, the normality test was carried out using the Shapiro-Wilk test due to $(\mathrm{N}<30)$. The data analysis used was paired t-test to see changes in the pre-test, post-test, and follow-up, and hypothesis testing was carried out using one repeated measure ANOVA test. 


\section{RESULTS AND DISCUSSION}

\section{Results}

The research data obtained were analyzed by SPSS and divided into descriptive data of the research participants based on pretest, post-test, follow up data, in the table below.

Table 1. Demographical

\begin{tabular}{lcc}
\hline Variables & $\mathrm{N}$ & $\%$ \\
\hline Age (years old) & & \\
14 & 1 & $6.2 \%$ \\
16 & 12 & $75 \%$ \\
17 & 3 & $18.8 \%$ \\
Gender & & \\
Male & 8 & $50 \%$ \\
Female & 8 & $50 \%$ \\
\hline
\end{tabular}

Table 2. Descriptive data of the experimental group

\begin{tabular}{lll}
\hline Group & M & SD \\
\hline T1 & 64 & 1.85 \\
T2 & 93 & 5.05 \\
T3 & 105.8 & 3.52 \\
\hline
\end{tabular}

Table 3. analysis results of within-subject

\begin{tabular}{lll}
\hline Time & T & $P$ \\
\hline T1 VS T2 & -18.391 & .56 \\
T2 VS T3 & -5.769 & .001 \\
T1 VS T3 & -30.549 & .001 \\
\hline
\end{tabular}

Table 4. Multiple comparisons (between groups)

\begin{tabular}{llll}
\hline Groups & MD & SE & $p$ \\
\hline MBCT - control & 12.62 & .87 & .001 \\
\hline
\end{tabular}

Table 5. Multiple comparisons (between groups)

\begin{tabular}{lllll}
\hline \multirow{2}{*}{ Humility } & $\mathrm{Df}$ & $\mathrm{F}$ & $P$ & $\eta_{\mathrm{p}}{ }^{2}$ \\
\cline { 2 - 5 } & 2 & 52,57 & .001 & .73 \\
\hline
\end{tabular}

Based on the data in table 1, the participants have an age range of 14-17 years and the number of participants based on gender is 8 male and female. However, the group division was carried out heterogeneously. All participants have never had the experience of practicing mindfulness and joining online group counseling.

Based on table 2, it shows that changes in humility experienced by students in the mindfulness group from $\mathrm{T} 1(\mathrm{M}=61.75 ; \mathrm{SD}=1.83)$, then $(\mathrm{M}=90.75 ; \mathrm{SD}=4.59)$ and $\mathrm{T} 3(\mathrm{M}$ $=105.87 ; \mathrm{SD}=3.52)$ are said to have increased. The humility is large enough because it exceeds one standard deviation. The table 3 explains that the ratio of $\mathrm{T} 1-\mathrm{T} 2(\mathrm{t}=18,391 ; \mathrm{p}=$ $.56), \mathrm{T} 2-\mathrm{T} 3(\mathrm{t}=-5,769, \mathrm{p}=.01)$ and $\mathrm{T} 1-\mathrm{T} 3(\mathrm{t}=-30.549, \mathrm{p}=.01)$ means that counseling the online mindfulness-based cognitive group and during that time experienced a significant and significant change in the humility score which was marked by $(\mathrm{p}<.05)$. So the research hypothesis is accepted that online group counseling with the mindfulness-based cognitive approach effectively increases humility.

Based on the data analysis for each treatment and time, the data in the explanation above were obtained, then the researcher also saw the differences between groups that were paired with a paired-wise comparisons analysis, obtained the following data.

Based on table 4, above it is known that the MBCT - Control (MD $=12.62 ; \mathrm{SE}=.87 ; \mathrm{p}$ $=.001)$ there is a significant change in the mean increase in humility. The results of the one- 
way-repeated Anova test on table 5 how that there is a significant interaction between students' humility in the group as evidenced by $(\mathrm{F}(2,4)=56,764, \mathrm{P}=.001, \Pi \mathrm{p} 2=.73$. Interpretation of the $\Pi p 2$ score shows an effect. big interaction because $\Pi p 2>.14$.

\section{Discussion}

So that, hypotheses 1 of the results showed that online group counseling with a mindfulness-based cognitive approach could effectively improve students' humility than the control group. In line with this, Maas et al. (2020) explained that e-MBCT or web-based MBCT is useful in intervention because clients are asked to practice independently for a week to understand the therapeutic goals achieved. There is a significant relationship between task prompting and intervention results.

Holländare et al. (2016) stated that a positive predictor of a treatment's success, namely a task that serves to encourage the achievement of goals (task prompting). This is also effective in e-MBCT rather than task reinforcement. Encouraging clients to do homework can lead them to practice more, which helps them. Mindfulness has three axioms that form the basis of its practice, including the first, the intensity of implementation. Group members who have seriousness in the on-going training process can indirectly influence self-regulation and good stress management so that they can to self-explore. Second, mindfulness in the process of practicing mindfulness also fosters awareness, and the third is an attitude; acceptance, openness, and positive thinking towards negative experiences are part of the focus on mindfulness attitudes (Shapiro et al., 2006). If viewed from the aspects of humility with the provision of mindfulness-based cognitive, it can be seen that individuals will increase their humility because the research subjects have the right self-perception followed by how individuals forgive themselves and others when they make mistakes/failures. Individuals who have high humility are also said to be humble.

Krause (2015) states that individuals who are humble when they are open and honest in their behavior, forgive themselves when they do something painful. Besides, Penrose (2010) states that humble individuals tend to appreciate the achievements made by others or themselves and understand their weaknesses. Individuals who have humility will be able to direct compassion for themselves and others. These aspects are contained in the provision of mindfulness-based cognitive interventions that are part of the treatment in the third session; developing gratitude and forgiveness through self-reflection and 3-minutes breathing). Moreover, in the fourth session; practice self-compassion with compassion and affirmation meditations on focusing on oneself and others.

Mindfulness and humility are correlated in empirical studies. Similar research, however, has not been revealed, but its significance to previous research, namely mindfulness and character strengths (e.g: Humility). Character strengths also help meet the needs of others in the social setting of the individual, in addition to contributing to social behavior (Niemiec et al., 2012). Linley et al. (2010) claimed that character strength could improve the academic goals of students. The practical principle of mindfulness identified by (Bishop et al., 2006) is that mindfulness requires self-regulation and attention (self-regulation $\&$ attention) and an attitude of curiosity, openness, and acceptance. In this sense, the elements of mindfulness are also included in humility indicators by operational concept, including openness, selfforgetfulness, accurate self-assessment, and focused on others.

Niemiec et al. (2012) suggested that mindfulness and character strengths are elements that human beings possess as a capacity for growth and development that can be combined to establish a positive effect of virtue. Via mindfulness, it can assist individuals to communicate the strengths of their character in a balanced, sensitive, and better direction to solve challenges by eventually paying attention. In real-life contexts, practice mindfulness may also be applied, so that life is aware, for instance, in this research, individuals do mindfulness in 
decision-making situations, learning and eating activities, and activities that include other people. The first is the self-regulation of attention, where the individual has an awareness of the experience, the feeling is fully present in the present moment. Besides, the focus is shifted from one object to another object flexibly. The attention raised will help optimize existing resources with existing information, generate perspectives on a broader experience, as well as metacognitive skills (self-regulation - monitoring self-awareness and control of cognitive processes). Second, experience orientation, meaning that individuals are in an active process to have a more open attitude and acceptance of new experiences and the thought process is also not self-centered. The choice of mindfulness as the basis for intervention is also based on the conceptual recommendations of (Waskito, 2019), it is necessary to conduct experimental research with mindfulness interventions so that the research results can help the counselor in choosing appropriate and useful interventions. Mindfulness practice can be applied to students to be able to be adaptive to themselves, others, and the environment through the practice of attention and awareness.

Furthermore, hypotheses 2 of the results describe that there are interaction effects between mindfulness group and control group in online group counseling. In their study, Jayawardene et al. (2017) reported that online mindfulness preventive interventions in nonclinical contexts, especially the academic setting, workplace, or community, can be significantly effective in reducing personal stress, particularly middle-aged people, and increasing attention. Considering the rise in digital access (Zickuhr \& Smith, 2012), in the academic and workplace climate, online mindfulness initiatives can be used as a more convenient and economical intervention technique, especially among young and middle-aged adults. Costs, not face to face. Dense human behavior makes it very difficult for a larger audience to access it digitally (Barak et al., 2009).

The success feature of online counseling is that the counselor can use psycho-education, empathy, self-disclosure, the formation of self-efficacy, strengthening of the partnership, flexibility in assignment deadlines, strengthening of tasks, and prompting tasks, all of which are linked to the outcomes of the intervention shown by a reduction in the client's symptoms (Paxling et al., 2013). Parsons et al. (2017) clarify that home practice is important because therapeutic improvements can be influenced. Weck et al. (2013) The skill of a therapist or counselor in presenting a handbook for the practice of mindfulness and performing a homework review is also an important factor, apart from the client itself who made the success of MBCT. Sipe \& Eisendrath (2012) suggested that mindfulness-based cognitive therapy focused on is characterized by distinguishing unhealthy and negative thoughts from positive thinking, testing and questioning dysfunctional values, seeking new meanings, and strengthening more adaptive responses. The contrast between an online-based intervention by a counselor or therapist is that they do not do "teaching" or specific guidance such as face-toface interventions. In particular, clients are mainly responsible for gaining theoretical information through reading, viewing online content, or other outlets that are often treated in weekly assignments/weekly modules (Maas et al., 2020).

Andersson (2018) also states that the role of therapists in online intervention has changed to help, such as offering guidance, providing input on worksheets conducted at home, or answering questions, since the therapist/counselor is not the key to the success of the client. Online sessions are also all about communication involving written messages or facial expressions or intonations that can also be inferred, using logos, for instance, or the like. They are dynamic in execution, which often includes client satisfaction, starting from their everyday context.

In 28 studies, a meta-analysis by Parsons et al. (2017) concluded that there was a positive correlation between in-home practice participants in MBCT and the effect of the intervention. So, better outcomes can be accomplished with increased exercise. Also, the e- 
MBCT program's intensity will play a role in achieving goals. Research conducted by Sánchez-Ortiz et al. (2011) indicates that online cognitive behavior therapy can promote behavioral change effectively. Internet-based, so that clients are more independent in information access and are responsible for following online modules so that the therapist's position becomes a natural supporter.

Parsons et al. (2017) results of research conducted with MBCT and MBSR that approximately 60 percent of research subjects perform regular activities at home to which respondents have substantially allocated time to regularly practice, but much less than expected in standard format interventions (Maas et al., 2020). Segal, Teasdale, \& Williams, (2013) the intervention results indicate promising evidence in treatment out. Compliance and self-awareness also impact the success factor of the intervention. Helbig \& Fehm (2004) added that the element of motivation to improve also affects homework completion. In their research Sedlmeier et al. (2012) found that the effect of meditation focused on mindfulness typically had a positive effect on psychological variables and a substantial effect on negative emotions rather than cognitive ones.

\section{Limitations and Suggestions}

This study has limitations, namely that the researcher does not measure the psychological attributes or psychological conditions of students other than humility and mindfulness. Further researchers can use other measurements to determine the factors that affect, such as anxiety, stress, depression, or burnout. Also, the number of research subjects is limited so that it cannot be generalized. Therefore, the researcher recommends further research for a larger and various sample research. Due to only comparing fellow online counseling groups, it can then be studied by comparing the effectiveness of online and faceto-face groups.

\section{Implications}

The research results are expected to have implications for counseling services in schools carried out in groups and online to be an effective, efficient and flexible strategy. The services can be implemented online, counselors and clients can adjust the implementation time specified. Character development in schools is the role of school counselors and one of them is humility. These are an important part of the development of character strengths and the personal and social fields. The impact of increasing humility includes students having a sense of optimism, integrity, forgiveness, kindness, academics, satisfaction, and well-being.

\section{CONCLUSION}

This study concludes is that online group counseling with a mindfulness-based cognitive approach can increase students' humility and show a relatively large interaction effect. Giving mindfulness interventions is effective because students also have more time to practice at home. Besides, mindfulness is a continued practice so that it can be implemented in daily activities. Humility is important to develop because it becomes another part of virtue development.

\section{ACKNOWLEDGMENTS}

This project is funded by the Indonesian Endowment Fund for Education (KET1/LPDP-4/2020), and Mrs. Aisyah., S.Pd as counselor coordinator of State Senior High School 9 Semarang and all participants. 


\section{AUTHOR CONTRIBUTIONS STATEMENT}

$\mathrm{RN}$ as a researcher, lead author, and idea developer. MEW \& $\mathrm{MM}$ as a supervisor who provides recommendations and validates treatment guidelines, and as proofreading of articles.

\section{REFERENCES}

Andersson, G. (2018). Internet interventions: Past, present and future. Internet Interventions, 12, 181-188. https://doi.org/10.1016/j.invent.2018.03.008

Barak, A., Klein, B., \& Proudfoot, J. G. (2009). Defining Internet-Supported Therapeutic Interventions. Annals of Behavioral Medicine, 38(1), 4-17. https://doi.org/10.1007/s12160-009-9130-7

Bronfenbrenner, U. (1992). Ecological systems theory. Jessica Kingsley Publishers. Google Scholar

Bishop, S. R., Lau, M., Shapiro, S., Carlson, L., Anderson, N. D., Carmody, J., Segal, Z. V., Abbey, S., Speca, M., Velting, D., \& Devins, G. (2006). Mindfulness: A Proposed Operational Definition. Clinical Psychology: Science and Practice, 11(3), 230-241. https://doi.org/10.1093/clipsy.bph077

Brown, K. W., \& Ryan, R. M. (2003). The benefits of being present: Mindfulness and its role in psychological well-being. Journal of Personality and Social Psychology, 84(4), 822848. https://doi.org/10.1037/0022-3514.84.4.822

Çardak, M. (2013). The relationship between forgiveness and humility: A case study for university students.Educational Research and Reviews, 8(8), 425-430. https://doi.org/10.5897/ERR2012.1071

Davis, D. E., Worthington, E. L., \& Hook, J. N. (2010). Humility: Review of measurement strategies and conceptualization as personality judgment. The Journal of Positive Psychology, 5(4), 243-252. https://doi.org/10.1080/17439761003791672

Elliott, J. C. (2010). Humility: Development and analysis of a scale. Ph.D Dissertation. University of Tennessee. Google Scholar

Helbig, S., \& Fehm, L. (2004). Problems with homework in cbt: rare exception or rather frequent? Behavioural and Cognitive Psychotherapy, 32(3), 291-301. https://doi.org/10.1017/S1352465804001365

Hernawati, Lucia., Sugiarto., DYP., Purwanto, Edy., \& Awalya. (2018). The effectiveness of cyber counseling service to enhance student performance in statistics. Advances in social science, education and humanities research (ASSEHR), 247. https://dx.doi.org/10.2991/iset-18.2018.63

Holländare, F., Gustafsson, S. A., Berglind, M., Grape, F., Carlbring, P., Andersson, G., Hadjistavropoulos, H., \& Tillfors, M. (2016). Therapist behaviours in internet-based cognitive behaviour therapy (ICBT) for depressive symptoms. Internet Interventions, 3, 1-7. https://doi.org/10.1016/j.invent.2015.11.002

Jayawardene, W. P., Lohrmann, D. K., Erbe, R. G., \& Torabi, M. R. (2017). Effects of preventive online mindfulness interventions on stress and mindfulness: A meta-analysis of randomized controlled trials. Preventive Medicine Reports, 5, 150-159. https://doi.org/10.1016/j.pmedr.2016.11.013

Kosim, M. (2012). Urgensi pendidikan karakter. KARSA: Journal of Social and Islamic Culture, 19(1), 84-92. http://dx.doi.org/10.19105/karsa.v19i1.78

Krause, N. (2015). Assessing the relationships among race, religion, humility, and selfforgiveness: A longitudinal investigation. Advances in Life Course Research, 24, 66-74. https://doi.org/10.1016/j.alcr.2015.02.003

Krumrei-Mancuso, E. J., Haggard, M. C., LaBouff, J. P., \& Rowatt, W. C. (2020). Links between intellectual humility and acquiring knowledge. The Journal of Positive Psychology, 15(2), 155-170. https://doi.org/10.1080/17439760.2019.1579359 
Kurnaedi, Nedi., Sugiharto., D.Y.P., \& Sunawan. (2020). The effectiveness of mindfulness deep breathing in clasical format to increase students' academic engagement. Jurnal Bimbingan Konseling. 10(1), 29-33. https://doi.org/10.15294/jubk.v10i1.35146

Lavelock, C. R., Worthington, E. L., Davis, D. E., Griffin, B. J., Reid, C. A., Hook, J. N., \& Van Tongeren, D. R. (2014). The Quiet Virtue Speaks: An Intervention to Promote Humility. Journal of Psychology and Theology, 42(1), 99-110. https://doi.org/10.1177/009164711404200111

Linley, P. A., Nielsen, K. M., Gillett, R., \& Biswas-Diener, R. (2010). Using signature strengths in pursuit of goals: Effects on goal progress, need satisfaction, and well-being, and implications for coaching psychologists. International Coaching Psychology Review, 5(1), 6-15. Google Scholar

Maas, A., Schellekens, M. P. J., van Woezik, R. A. M., \& van der Lee, M. L. (2020). Therapist behaviours in a web-based mindfulness-based cognitive therapy (eMBCT) for chronic cancer-related fatigue - Analyses of e-mail correspondence. Internet Interventions, 22, 100355. https://doi.org/10.1016/j.invent.2020.100355

Niemiec, R., Rashid, T., \& Spinella, M. (2012a). Strong Mindfulness: Integrating Mindfulness and Character Strengths. Journal of Mental Health Counseling, 34(3), 240-253. https://doi.org/10.17744/mehc.34.3.34p6328x2v204v21

Niemiec, R., Rashid, T., \& Spinella, M. (2012b). Strong Mindfulness: Integrating Mindfulness and Character Strengths. Journal of Mental Health Counseling, 34(3), 240-253. https://doi.org/10.17744/mehc.34.3.34p6328x2v204v21

Nurhaeda, N., Sutoyo, A., \& Mulawarman, M. (2020). Mindfulness Training with Deepbreathing Techniques to Increase Disability Resilience. Proceedings of the Proceedings of the 5th International Conference on Science, Education and Technology, ISET 2019, https://doi.org/10.4108/eai.29-6-2019.2290355

Orcutt, H. K. (2006). The prospective relationship of interpersonal forgiveness and psychological distress symptoms among college women. Journal of Counseling Psychology, 53(3), 350-361. https://doi.org/10.1037/0022-0167.53.3.350

Pang, D., \& Ruch, W. (2019). The Mutual Support Model of Mindfulness and Character Strengths. Mindfulness, 10(8), 1545-1559. https://doi.org/10.1007/s12671-019-01103-Z

Parsons, C. E., Crane, C., Parsons, L. J., Fjorback, L. O., \& Kuyken, W. (2017). Home practice in Mindfulness-Based Cognitive Therapy and Mindfulness-Based Stress Reduction: A systematic review and meta-analysis of participants' mindfulness practice and its association with outcomes. Behaviour Research and Therapy, 95, 29-41. https://doi.org/10.1016/j.brat.2017.05.004

Paxling, B., Lundgren, S., Norman, A., Almlöv, J., Carlbring, P., Cuijpers, P., \& Andersson, G. (2013). Therapist behaviours in internet-delivered cognitive behaviour therapy: Analyses of e-mail correspondence in the treatment of generalized anxiety disorder. Behavioural and Cognitive Psychotherapy, 41(3), 280-289. https://doi.org/10.1017/S1352465812000240

Penrose, B. (2010). Humility and Understanding. Philosophical Papers, 39(3), 427-455. https://doi.org/10.1080/05568641.2010.538917

Permatasari, D. (2015). Menumbuhkan Kerendahan Hati Siswa SMP Melalui Konseling Kelompok Analisis Transaksional. Proceedings Konferensi Nasional" Mempersiapkan Kebangkitan Generasi Emas Indonesia 2045 Melalui Revolusi Mental Anak Bangsa", 1(1), 325-343. Google Scholar

Rodríguez-Ledo, C., Orejudo, S., Cardoso, M. J., Balaguer, Á., \& Zarza-Alzugaray, J. (2018). Emotional Intelligence and Mindfulness: Relation and Enhancement in the Classroom With Adolescents. Frontiers in Psychology, 2162. https://doi.org/10.3389/fpsyg.2018.02162 
Rowatt, W. C., Powers, C., Targhetta, V., Comer, J., Kennedy, S., \& Labouff, J. (2006). Development and initial validation of an implicit measure of humility relative to arrogance. The Journal of Positive Psychology, 1(4), 198-211. https://doi.org/10.1080/17439760600885671

Sánchez-Ortiz, V. C., Munro, C., Stahl, D., House, J., Startup, H., Treasure, J., Williams, C., \& Schmidt, U. (2011). A randomized controlled trial of internet-based cognitivebehavioural therapy for bulimia nervosa or related disorders in a student population. Psychological Medicine, 41(2), 407-417. https://doi.org/10.1017/S0033291710000711

Sandage, S. J., Jankowski, P. J., Bissonette, C. D., \& Paine, D. R. (2017). Vulnerable narcissism, forgiveness, humility, and depression: Mediator effects for differentiation of self. Psychoanalytic Psychology, 34(3), 300. http://dx.doi.org/10.1037/pap0000042

Sariçam, H. et. al. (2012). The Turkish Version of The Humility Scale: The Study of Validity and Reliability. Kalem Eğitim ve Insan Bilimleri Dergisi, 2(2), 165-188. Google Scholar

Sedlmeier, P., Eberth, J., Schwarz, M., Zimmermann, D., Haarig, F., Jaeger, S., \& Kunze, S. (2012). The psychological effects of meditation: A meta-analysis. Psychological Bulletin, 138(6), 1139-1171. https://doi.org/10.1037/a0028168

Segal, Z. V., Teasdale, J. D., \& Williams, J. M. G. (2013). Midfulnes based cognitive therapy. New York: The Guilford Press. https://doi.org/10.1891/0889-8391.28.2.147

Shapiro, S. L., Carlson, L. E., Astin, J. A., \& Freedman, B. (2006). Mechanisms of mindfulness. Journal of Clinical Psychology, 62(3), 373-386. https://doi.org/10.1002/jclp.20237

Singh, N. N., Lancioni, G. E., Wahler, R. G., Winton, A. S. W., \& Singh, J. (2008). Mindfulness Approaches in Cognitive Behavior Therapy. Behavioural and Cognitive Psychotherapy, 36(6), 659-666. https://doi.org/10.1017/S1352465808004827

Sipe, W. E. B., \& Eisendrath, S. J. (2012). Mindfulness-Based Cognitive Therapy: Theory and Practice. The Canadian Journal of Psychiatry, 57(2), 63-69. https://doi.org/10.1177/070674371205700202

Siradjuddin, H. K. (2017). Implementasi Prototype Aplikasi E-Konseling Untuk Menunjang Pelayanan Konseling Berbasis Jejaring Sosial. IJIS-Indonesian Journal On Information System, 2(2). https://doi.org/10.36549/ijis.v2i2.29

Snyder, C. R., \& Lopez, S. J. (2009). Handbook of positive psychology. Oxford University Press. Google Scholar

Susanti, P. D., Mungin Eddy Wibowo, M. E. W., \& Mulawarman, M. (2019). The Effectiveness of Acceptance and Commitment Therapy Counseling and Mindfulnessbased Cognitive Counseling to Reduce School Burnout. Jurnal Bimbingan Konseling, 8(4), 173-178. https://doi.org/10.15294/jubk.v9i2.34352

Tadlock-Marlo, R. L. (2011). Making Minds Matter: Infusing Mindfulness Into School Counseling. Journal of Creativity in Mental Health, 6(3), 220-233. https://doi.org/10.1080/15401383.2011.605079

Tangney, J. P. (2000). Humility: Theoretical Perspectives, Empirical Findings and Directions for Future Research. Journal of Social and Clinical Psychology, 19(1), 70-82. https://doi.org/10.1521/jscp.2000.19.1.70

Ussolikhah, N. (2017). Studi tentang penggunaan cybercounseling untuk layanan konseling individual bersama mahasiswa program studi Bimbingan dan Konseling UNU Cirebon. Oasis: Jurnal Ilmiah Kajian Islam, 2(1), 28-43. Google Scholar

Van Doesum, N. J., de Vries, R. E., Blokland, A. A. J., Hill, J. M., Kuhlman, D. M., Stivers, A. W., Tybur, J. M., \& Van Lange, P. A. M. (2020). Social mindfulness: Prosocial the active way. The Journal of Positive Psychology, 15(2), 183-193. https://doi.org/10.1080/17439760.2019.1579352 
Van Tongeren, D. R., Davis, D. E., Hook, J. N., \& Witvliet, C. vanOyen. (2019). Humility. Current Directions in Psychological Science, 28(5), 463-468. https://doi.org/10.1177/0963721419850153

Vernon, A., \& Doyle, K. A. (2017). Cognitive Behavior Therapies: A Guidebook for Practitioners. John Wiley \& Sons. Google Scholar

Waskito, P. (2019). Mindfulness dalam Layanan Bimbingan dan Konseling bagi Peserta Didik Remaja di Sekolah Menengah Pertama. Konvensi Nasional Bimbingan dan Konseling XXI, 115-121. Google Scholar

Weber, M., Ruch, W., Littman-Ovadia, H., Lavy, S., \& Gai, O. (2013). Relationships among higher-order strengths factors, subjective well-being, and general self-efficacy - The case of Israeli adolescents. Personality and Individual Differences, 55(3), 322-327. https://doi.org/10.1016/j.paid.2013.03.006

Weck, F., Richtberg, S., Esch, S., Höfling, V., \& Stangier, U. (2013). The Relationship Between Therapist Competence and Homework Compliance in Maintenance Cognitive Therapy for Recurrent Depression: Secondary Analysis of a Randomized Trial. Behavior Therapy, 44(1), 162-172. https://doi.org/10.1016/j.beth.2012.09.004

Wright, J. C., Nadelhoffer, T., Perini, T., Langville, A., Echols, M., \& Venezia, K. (2017). The psychological significance of humility. The Journal of Positive Psychology, 12(1), 3-12. https://doi.org/10.1080/17439760.2016.1167940

Zickuhr, K., \& Smith, A. (2012). While increased internet adoption and the rise of mobile connectivity have reduced many gaps in technology access over the past decade, for some groups digital disparities remain. 41. Google Scholar



